\title{
PREDIKSI BEBAN ENERGI LISTRIK APJ KOTA SEMARANG MENGGUNAKAN METODE RADIAL BASIS FUNCTION (RBF)
}

\author{
Mukti Dwi Cahyo ${ }^{1)}$, Sri Heranurweni ${ }^{2)}$, Harmini ${ }^{3)}$ \\ ${ }^{123)}$ Program Studi Teknik Elektro, Fakultas Teknik, Universitas Semarang \\ Jalan Soekarno Hatta - Tlogosari, Semarang, Indonesia, 50196 \\ email: $\underline{\text { muktidwicahyo10@yahoo.com }}{ }^{1)}, \underline{\text { heranur@usm.ac.id }}{ }^{2)}$, harmini@usm.ac.id $^{3)}$
}

\begin{abstract}
Electric power is one of the main needs of society today, ranging from household consumers to industry. The demand for electricity increases every year. So as to achieve adjustments between power generation and power demand, the electricity provider (PLN) must know the load needs or electricity demand for some time to come. There are many studies on the prediction of electricity loads in electricity, but they are not specific to each consumer sector.

One of the predictions of this electrical load can be done using the Radial Basis Function Artificial Neural Network (ANN) method. This method uses training data learning from 2010 - 2017 as a reference data. Calculations with this method are based on empirical experience of electricity provider planning which is relatively difficult to do, especially in terms of corrections that need to be made to changes in load. This study specifically predicts the electricity load in the Semarang Rayon network service area in 2019-2024.

The results of this Artificial Neural Network produce projected electricity demand needs in 2019-2024 with an average annual increase of 1.01\% and peak load in 2019-2024. The highest peak load in 2024 and the dominating average is the household sector with an increase of $1 \%$ per year. The accuracy results of the Radial Basis Function model reached $95 \%$.
\end{abstract}

Keywords: Artificial neural networks, electrical loads, predictions, radial basis function models

\begin{abstract}
ABSTRAK
Tenaga listrik merupakan salah satu kebutuhan utama masyarakat saat ini,mulai dari konsumen rumah tangga hingga industri. Permintaan akan tenaga listrik meningkat setiap tahun. Sehingga untuk mencapai penyesuaian antara pembangkit dan permintaan tenaga, penyedia listrik (PLN) harus mengetahui kebutuhan beban atau permintaan listrik untuk beberapa waktu mendatang. Ada banyak penelitian tentang prediksi (perkiraan) beban listrik dalam listrik, tetapi tidak spesifik untuk setiap sektor konsumen.

Prediksi beban listrik ini dapat dilakukan salah satunya dengan menggunakan metode Jaringan Syaraf Tiruan (JST) Radial Basis Function. Metode ini menggunakan pembelajaran data pelatihan dari 2010 - 2017 sebagai data referensi. Perhitungan dengan metode ini didasarkan pada pengalaman empiris perencanaan penyedia listrik yang relatif sulit dilakukan, terutama dalam hal koreksi yang perlu dilakukan terhadap perubahan beban. Penelitian ini secara khusus memprediksi beban listrik di wilayah layanan jaringan Rayon Semarang pada 2019-2024.

Hasil dari Jaringan Syaraf Tiruan ini menghasilkan proyeksi kebutuhan beban listrik pada 2019-2024 dengan peningkatan tahunan rata-rata 1,01\% dan beban puncak pada 2019-2024. Beban puncak tertinggi pada tahun 2024 dan rata-rata yang mendominasi adalah sektor rumah tangga dengan kenaikan $1 \%$ per tahun. Hasil akurasi fungsi model Radial Basis Function mencapai $95 \%$.
\end{abstract}

Kata kunci: Jaringan syaraf tiruan, beban listrik, prediksi, radial basis function

\section{Pendahuluan}

$\mathrm{E}$ nergi listrik merupakan salah satu kebutuhan utama masyarakat saat ini, mulai dari konsumen rumah tangga hingga industri. Permintaan akan tenaga listrik meningkat setiap tahun, sehingga untuk mencapai penyesuaian antara pembangkit dan permintaan tenaga listrik, maka sebagai penyedia energi listrik yaiu PLN harus mengetahui kebutuhan beban atau permintaan energi listrik untuk beberapa tahun berikutnya. Ada banyak penelitian tentang prediksi (perkiraan) beban listrik dalam listrik, tetapi tidak spesifik untuk setiap sektor konsumen.

Prakiraan permintaan beban listrik berdasarkan jangka waktu dapat dikelompokan dalam :
1. Prakiraan beban jangka panjang (long term) adalah prakiraan permintaan beban dengan jangka waktu diatas 1 (satu) tahun.

2. Prakiraan beban jangka menengah (medium term) adalah prakiraan permintaan beban dengan jangka waktu satu bulan sampai dengan satu tahun.

3. Prakiraan beban jangka pendek (short term) adalah prakiraan permintaan beban dengan jangka waktu beberapa jam dalam satu hari sampai dengan satu minggu [4].

Oleh karena itu, penelitian ini menggunakan aplikasi jaringan syaraf tiruan (JST) dengan pembelajaran model Radial Basis Function. Keuntungan yang didapatkan dari hasil pembuatan sistem ini adalah mampunyai penyedia listrik untuk memprediksi kebutuhan 
energi listrik sesuai dengan kebutuhan konsumen listrik. data yang digunakan pada penelitian ini dari APJ (Area Pelayanan Jaringan) Rayon Semarang.

\section{DASAR TEORI}

\subsection{Jaringan Syaraf Tiruan RBF (Radial Basis Function)}

RBF adalah jaringan syaraf tiruan yang menggabungkan metode pelatihan terbimbing dan metode pelatihan tanpa pengawasan. Jaringan syaraf ini dibentuk menggunakan fungsi Basis Radial sehingga disebut RBF Neural Network.

Topologi jaringan dalam RBF terdiri dari 3 lapisan, yaitu lapisan input, lapisan atau unit tersembunyi dan lapisan keluaran. Setiap unit tersembunyi adalah fungsi aktivasi dalam bentuk fungsi basis radial. Fungsi dasar radial ini terkait dengan posisi dasar dan lebar fungsi dasar. Struktur dasar jaringan RBF dapat dilihat pada Gambar 1[1].

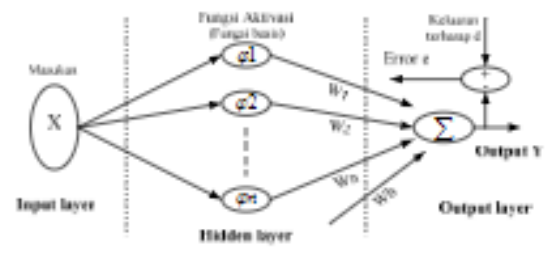

Gambar 1. Struktur Dasar Jaringan Syaraf RBF (Hariyanto,2005)

Setiap input dari jaringan syaraf tiruan RBF ini akan mengaktifkan semua fungsi dasar di lapisan tersembunyi. Setiap unit dari lapisan tersembunyi adalah fungsi aktivasi khusus yang disebut fungsi dasar. Di dalam lapisan tersembunyi ada sejumlah fungsi dasar yang serupa. Setiap fungsi dasar akan menghasilkan output dengan bobot tertentu. Keluaran jaringan ini adalah jumlah dari semua fungsi basis keluaran dikalikan dengan bobot masing-masing.

\subsection{Struktur Jaringan RBF}

Jaringan Radial Basis Function (RBF) terdiri dari:

a. Lapisan Input

Lapisan input adalah bagian dari rangkaian jaringan syaraf tiruan RBF sebagai input untuk melakukan proses pertama. Lapisan ini membaca data dari faktor eksternal, yaitu output (unit sensor) dan nilai yang diinginkan (referensi). Lapisan input ini tidak memiliki algoritma khusus, tetapi hanya sebagai pelengkap untuk lapisan berikutnya. Tahap awal ini ditentukan sebagai identifikasi awal

b. Lapisan Tersembunyi

Pada bagian ini kegiatan formulasi terjadi dalam pembentukan sistem algoritma yang digunakan dalam jaringan RBF. Lapisan kedua adalah lapisan tersembunyi dari dimensi yang lebih tinggi, yang melayani tujuan fungsi dasarnya dan menimbang nilai yang berbeda. Bagian lapisan tersembunyi adalah proses mengaktifkan fungsi dasar dan korelasi silang dari masing-masing fungsi dasar. Dalam lapisan tersembunyi ini, selain memuat bobot, juga memuat fungsi basis. Dalam jaringan RBF fungsi basis ini identik dengan fungsi gaussian seperti pada persamaan (1) di bawah ini:

$$
\varphi_{j}=e^{-\frac{\left\|c-x_{j}\right\|^{2}}{2 d^{2}}}
$$

dimana :

$\mathrm{c}=$ Center fungsi gausiaan

$\mathrm{d}=$ Lebar fungsi gausiaan

$\mathrm{xj}=$ Masukan ke $\mathrm{j}$

$\varphi j=$ Keluaran fungsi basis oleh adanya masukan $x j$ c. Lapisan Keluaran

Hasil penjumlahan dari perkalian bobot dan fungsi dasar menghasilkan keluaran yaitu lapisan keluaran, yang merespons jaringan sesuai dengan pola. Transformasi dari lapisan input ke pemrosesan sinyal lapisan tersembunyi adalah non-linier tetapi transformasi dari lapisan tersembunyi ke lapisan output adalah linier [9].

\subsection{Algoritma Pelatihan RBF}

Algoritma pelatihan RBF yang berulang adalah sebagai berikut:

Langkah 1: Menentukan jumlah fungsi dasar yang akan digunakan.

Langkah 2: Menentukan pusat dari masing-masing fungsi basis.

Langkah 3: Memberikan bobot (fungsi dasar) dari $\mathrm{n}+$ 1 , di mana $n$ adalah jumlah input RBF.

Langkah 4: Menginisialisasi bobot dengan $\mathrm{w}=\left[\begin{array}{lll}0 & 0 & 0\end{array}\right.$ $0]$, masukkan tingkat konvergensi yang digunakan $(0<\alpha$ $<1)$.

Langkah 5: Untuk setiap seri sinyal, kerjakan pada langkah 6 hingga selesai.

Langkah 6: Menghitung output dari setiap fungsi dasar. Langkah 7: Menghitung output jaringan RBF.

Langkah 8: Menghitung kesalahan antara sinyal yang diharapkan (d) dan output RBF y_error $=\mathrm{d}-\mathrm{y}$.

Langkah 9: Memperbarui bobot untuk setiap fungsi dasar dan bobot dasar menggunakan metode LMS [7].

\subsection{Sistem Ketenagalistrikan Provinsi Jawa Tengah}

Sistem ketenagalistrikan Provinsi Jawa Tengah merupakan bagian dari satu kesatuan sistem di Pulau Jawa, Pulau Madura dan Pulau Bali (JAMALI) yang terhubung secara interkoneksi dengan Saluran Udara Tegangan Ekstra Tinggi (SUTET) $500 \mathrm{kV}$ dan Saluran Udara Tegangan Tinggi (SUTT) $150 \mathrm{kV}$, kecuali wilayah di Pulau Karimun Jawa.

Wilayah Kepulauan Karimun Jawa merupakan wilayah di Provinsi Jawa Tengah yang tidak terhubung dengan sistem JAMALI, karenamerupakan pulau terluar di Provinsi Jawa Tengah. Pasokan energi di Karimun Jawa disuplai oleh PLTD Legon Bajakdengan kapasitas sebesar 2x2,2 MW sehingga mulai tahun 2016 penduduk di Karimun Jawa sudah dapat menikmati listrik 24 jam. 
Pembangkit di Jawa Tengah terhubung dengan system interkoneksi JAMALI, terdiri dari pembangkit termis dan beberapa pembangki thidro. Total kapasitas pembangki tterpasang di Jawa Tengah sebesar 7.299,97 MW, terdiri dari pembangkit yang tersambung dalam jaringan transmisi sebesar 7.251,56 MW, dan pembangkit yang tersambun gdalam jaringan distribusi sebesar 48,41 MW [3].

\section{METODOLOGI PENELITIAN}

\section{Diagram Blok}

a. Diagram blok data latih :

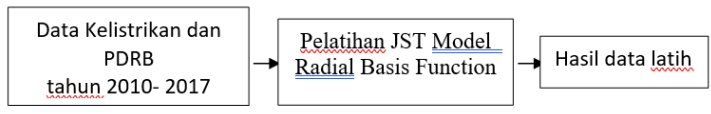

Gambar 2. Sistem Data Latih

b. Diagram blok pengujian :

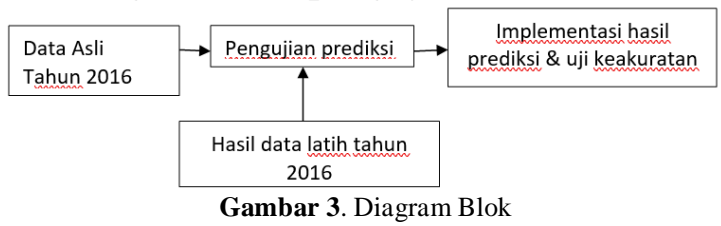

Pada diagram blok diatas, data latih $\mathrm{kWh}$ pada tahun 2012-2018. Proses pelatihan dan pengujian menggunakan Model Radial Basis Function (RBF). Saat pengujian, data hasil pelatihan kemudian dibandingkan melalui pengujian prediksi, kemudian diperoleh implementasi hasil prediksi dan uji keakuratan.

\subsection{Data Kelistrikan}

Data Kelistrikan diperoleh dari BPS (Badan Pusat Statistik) Provinsi Jawa Tengah berupa data jumlah pelanggan listrik, jumlah konsumsi energi listrik, dan daya tersambung pada tiap-tiap sektor di Kota Semarang.

\section{a. Jumlah Pelanggan Listrik}

Pelanggan listrik dibagi menjadi 4 kelompok sektor pemakai yaitu Rumah Tangga, Bisnis, Publik, dan Industri. Berikut jumlah pelanggan listrik Provinsi Jawa Tengah per Area tahun 2010 hingga tahun 2017.

Tabel 1. Jumlah Pelanggan Listrik Semarang

\begin{tabular}{r|r|r|r|r|}
\hline TAHUN & RUMAH TANGGA & \multicolumn{1}{|c|}{ Industri } & \multicolumn{1}{c|}{ Bisnis } & PUBLIK \\
\hline 2010 & 785012 & 448306 & 292352 & 79139 \\
\hline 2011 & 844338 & 498105 & 330055 & 89458 \\
\hline 2012 & 907331 & 539516 & 355718 & 101426 \\
\hline 2013 & 978060 & 603579 & 390105 & 113652 \\
\hline 2014 & 1020017 & 633869 & 414991 & 121764 \\
\hline 2015 & 1067047 & 657133 & 452922 & 131693 \\
\hline 2016 & 1084672 & 687545 & 473927 & 149872 \\
\hline 2017 & 1109873 & 706846 & 498553 & 167893 \\
\hline
\end{tabular}

\section{b. Konsumsi Energi Listrik}

Sebagian besar kebutuhan energi listrik Kota Semarang disuplai oleh pembangkit-pembangkit listrik yang terkoneksi dengan sistem transmisi JAMALI (Jawa-Madura-Bali) $150 \mathrm{kV}$ dan $500 \mathrm{kV}$. Berikut jumlah konsumsi energi listrik Provinsi Jawa Tengah per Area tahun 2010 hingga tahun 2017.

\begin{tabular}{|r|r|r|r|r|}
\multicolumn{5}{|c|}{ Tabel 2. Konsumsi Energi Listrik Semarang } \\
\hline TAHUN & RUMAH TANGGA & Industri & \multicolumn{1}{|c|}{ Bisnis } & \multicolumn{1}{c|}{ PUBLIK } \\
\hline 2010 & 1306131 & 1290351 & 551150 & 126643 \\
\hline 2011 & 1390960 & 1416852 & 588517 & 138681 \\
\hline 2012 & 1517811 & 1528677 & 631305 & 155815 \\
\hline 2013 & 1630797 & 1649611 & 669719 & 174694 \\
\hline 2014 & 1753642 & 1779028 & 703581 & 194284 \\
\hline 2015 & 1847006 & 1788810 & 733670 & 213476 \\
\hline 2016 & 1896371 & 1808518 & 763954 & 233510 \\
\hline 2017 & 1956070 & 1986423 & 795087 & 242924 \\
\hline
\end{tabular}

\section{c. Daya Tersambung}

Daya tersambung yang terhubung atau terkoneksi dengan masing-masing Area Kota Semarang ditunjukkan pada tabel 3 di bawah ini.

Tabel 3. Daya Tersambung Listrik Semarang

\begin{tabular}{r|r|r|r|r|}
\hline TAHUN & RUMAH TANGGA & \multicolumn{1}{|c|}{ Industri } & \multicolumn{1}{c|}{ Bisnis } & PUBLIK \\
\hline 2010 & 785012 & 448306 & 292352 & 79139 \\
\hline 2011 & 844338 & 498105 & 330055 & 89458 \\
\hline 2012 & 907331 & 539516 & 355718 & 101426 \\
\hline 2013 & 978060 & 603579 & 390105 & 113652 \\
\hline 2014 & 1020017 & 633869 & 414991 & 121764 \\
\hline 2015 & 1067047 & 657133 & 452922 & 131693 \\
\hline 2016 & 1084672 & 687545 & 473927 & 149872 \\
\hline 2017 & 1109873 & 706846 & 498553 & 167893 \\
\hline
\end{tabular}

\section{d. PDRB}

Produk Domestik Regional Bruto (PDRB) merupakan salah satu indikator pertumbuhan ekonomi suatu daerah. PDRB Provinsi Jawa Tengah tahun 2012-2016 adalah sebagai berikut :

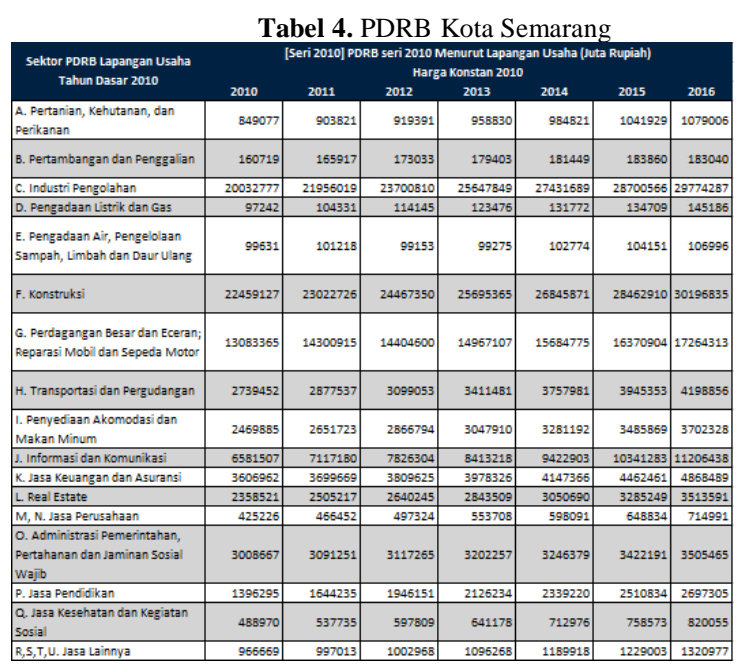




\section{HASIL DAN ANALISA}

\subsection{Hasil Pelatihan}

Data yang bersumber dari Badan Pusat Statistik ini dirubah kedalam bilangan desimal dikarenakan jaringan saraf tiruan radial basis function dapat mengolah bilangan prediksi dengan baik dengan hasil bilangan desimal. Sebelum dirubah kedalam bentuk bilangan desimal atau data norm, maka data di kecilkan nilainya agar sistem jaringan syaraf tiruan dapat mengenali dengan baik pola bilangan yang akan dilatih.

Tabel 5. Parameter JST Radial Basis Function

\begin{tabular}{|l|c|}
\hline Target Performa (MSE) & $1,00 \mathrm{E}-05$ \\
\hline Spread konstan & 6 \\
\hline Jumlah Maksimal Neuron & 80 \\
\hline Jumlah Neuron dibelakang layar & 100 \\
\hline Fungsi parameter pelatihan & traingdx \\
\hline Epoch & 1000 \\
\hline Iterasi & 1000 \\
\hline Learning Rate & 0,00000513 \\
\hline Gradient & 0.126 \\
\hline
\end{tabular}

Tabel 6. Hasil Keakuratan Pelatihan

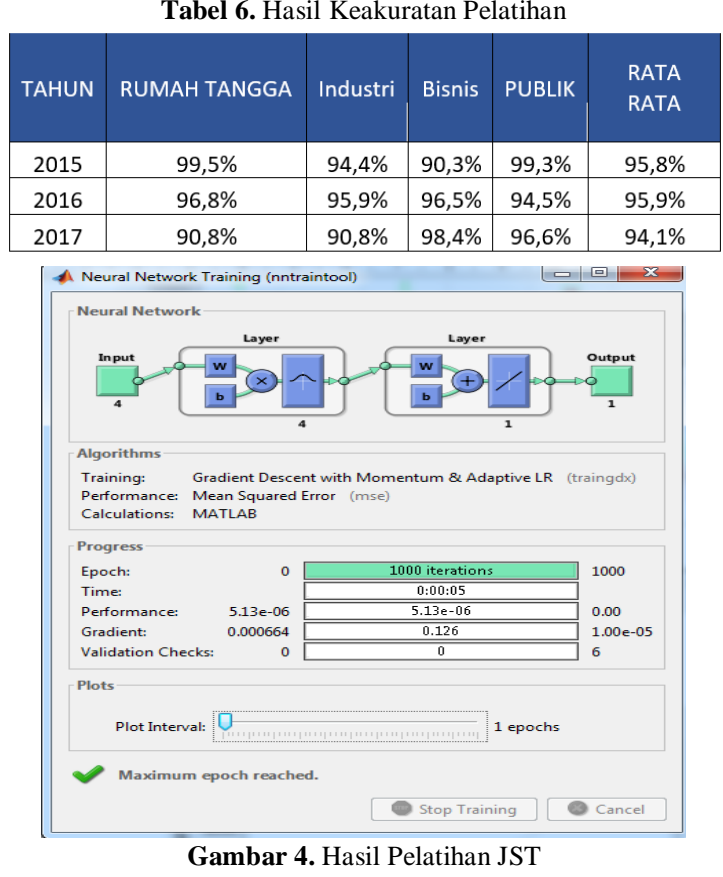

A. Analisa

\section{Proyeksi Kebutuhan Energi Kota Semarang}

Kebutuhan energi di Kota Semarang seperti pada tabel 2 menunjukkan bahwa pada tahun 2016 sampai tahun 2017 terjadi kenaikan atau pertumbuhan kebutuhan energi yaitu sebesar 1,09\% untuk energi produksi (MWh) dan kenaikan kebutuhan beban puncak (MW) sebesar 1,09\%. Proyeksi kebutuhan untuk tahun 20182024 berdasarkan 4 faktor yaitu faktor pelanggan listrik, daya tersambung, konsumsi energi dan faktor PDRB di Kota Semarang. Perhitungan didasarkan ke empat faktor tersebut dalam hal ini melihat pertumbuhan pada masing masing faktor per tahun, berikut perhitungan kebutuhan energi di kota semarang mencakup energi yang harus di produksi dan saat beban puncak.

Diketahui data energi tahun 2016-2017 yaitu :
Tabel 7. Data Energi Produksi dan Beban Puncak

\begin{tabular}{|c|c|c|}
\hline TAHUN & $\begin{array}{c}\text { ENERGI PRODUKSI } \\
\text { (MWh) }\end{array}$ & $\begin{array}{c}\text { BEBAN PUNCAK } \\
\text { (MW) }\end{array}$ \\
\hline 2016 & 819118 & 111 \\
\hline 2017 & 898695 & 122 \\
\hline
\end{tabular}

Berdasarkan tabel 7 diketahui bahwa energi yang diproduksi pada tahun 2017 meningkat sebesar 1,09\% dan untuk beban puncak meningkat sebesar $1,09 \%$. Dari data tersebut maka didapat kalkulasi untuk kebutuhan energi tahun 2018 yaitu :

Energi Produksi (2018) $=\left(\left(\frac{(p+e+d+p d r b)}{4}\right) \times\right.$ Ep 2017)

Dengan :

$\mathrm{p}=$ rata rata pertumbuhan pelanggan 2018

$\mathrm{e}=$ rata rata pertumbuhan konsumsi energi 2018

$\mathrm{d}=$ rata rata pertumbuhan daya tersambung 2018

pdrb $=$ rata rata pertumbuhan pdrb 2018

Ep 2017 = Energi Produksi tahun 2017

\section{B. Hasil Proyeksi Kebutuhan Energi 2018-2024}

Berdasarkan perhitungan maka didapat hasil perhitungan proyeksi prediksi energi yang harus diproduksi dan beban puncak di kota semarang periode 2018-2024 seperti pada tabel 8 .

Tabel 8. Hasil Proyeksi Tahun 2018-2024

\begin{tabular}{|r|c|c|}
\hline TAHUN & ENERGI PRODUKSI (MWh) & BEBAN PUNCAK (MW) \\
\hline 2016 & 819118 & 111 \\
\hline 2017 & 898695 & 122 \\
\hline 2018 & 927902 & 126 \\
\hline 2019 & 976616 & 133 \\
\hline 2020 & 1032771 & 137 \\
\hline 2021 & 1128302 & 149 \\
\hline 2022 & 1232669 & 162 \\
\hline 2023 & 1325119 & 174 \\
\hline 2024 & 1494071 & 196 \\
\hline
\end{tabular}

\section{ENERGI PRODUKSI (MWh)}

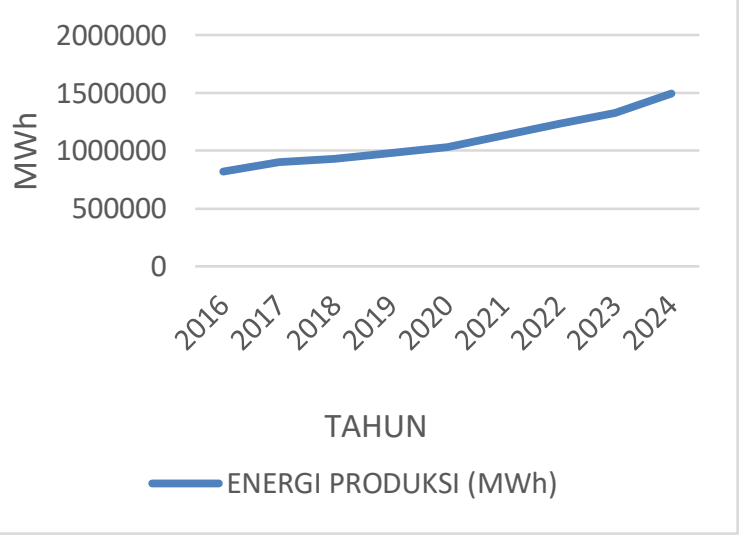

Gambar 5. Grafik Energi Produksi 


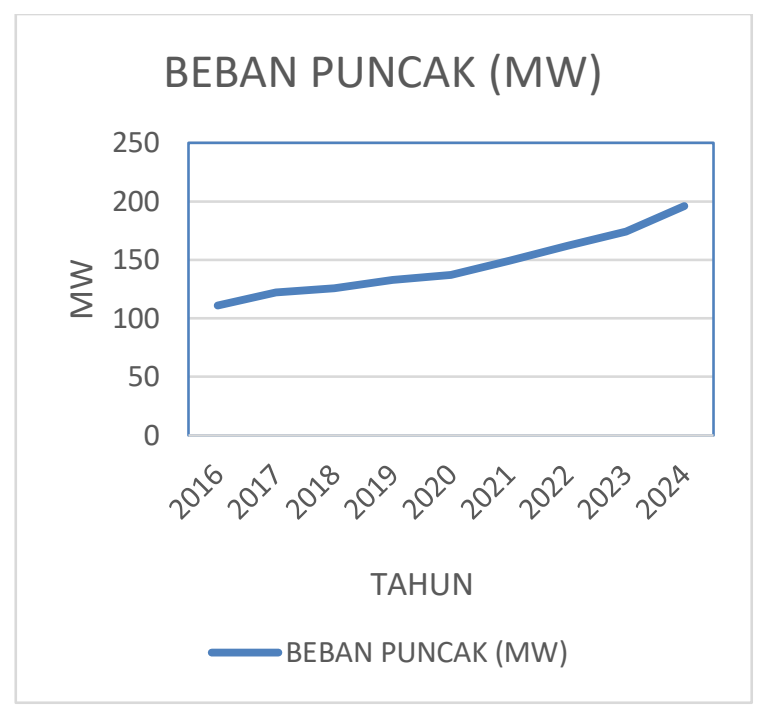

Gambar 6. Grafik Beban Puncak

\section{PENUTUP}

Berdasarkan hasil pengujian dan analisa maka dapat diambil kesimpulan yaitu :

1. Pertumbuhan kebutuhan energi dan beban puncak sehubungan dengan pertumbuhan sektor pelanggan listrik, daya tersambung listrik, konsumsi energi listrik dan pertumbuhan PDRB Kota Semarang.

2. Kenaikan kebutuhan energi pada tahun 2018 mencapai $1,03 \%$, pada tahun 2019-2020 mengalami kenaikan mencapai $1,05 \%$, pada tahun 2021-2022 mengalami kenaikan kembali menjadi $1,09 \%$, pada tahun 2023 mengalami penurunan 1,07\% dan pada tahun 2024 mengalami kenaikan yang cukup signifikan yaitu $1,12 \%$.

3. Dari hasil rata-rata proyeksi pelanggan listrik Kota Semarang pada 4 sektor yaitu sektor rumah tangga, industri, bisnis dan publik pada tahun 2018-2024 yang paling tertinggi adalah sektor rumah tangga dengan kenaikan rata-rata mencapai $1 \%$ per tahun.

4. Dari hasil rata-rata daya tersambung Kota Semarang pada 4 sektor yaitu sektor rumah tangga, industri, bisnis dan publik pada tahun 2018-2023 yang tertinggi adalah sektor rumah tangga dengan ratarata kenaikan di angka 0,9\% dan pada tahun 2024 yang tertinggi sekto industri di angka 1,3\%.

5. Dari hasil rata-rata konsumsi energi Kota Semarang pada 4 sektor yaitu sektor rumah tangga, industri, bisnis, dan publik pada tahun 2018-2024 didominasi oleh sektor rumah tangga dan industri dengan masing-masing kenaikan di angka $0,88 \%$ dan di angka $0,98 \%$.

\section{DAFTAR PUSTAKA}

[1] Arief, Hariyanto. 2005. Jaringan Syaraf Tiruan dan Teori Aplikasi Pemogramanya. Surabaya

[2] Badan Pusat Statistik Jawa Tengah Dalam Angka 2010 - 2017
[3] Data Kelistrikan PLN Tahun 2014, 2016 dan 2017

[4] Hasan Basri, Ir.,2003. Teknik Distribusi Jaringan Listrik Menengah Dan Tegangan Tinggi. Jakarta

[5] Hasim Agus. 2015 .Prakiraan Beban Listrik Kota Pontianak Dengan Jaringan Syaraf Tiruan. Skripsi Sekolah Pasca Sarjana Institut Pertanian Bogor.

[6] Hermawan, 2008. Sistem Distribusi Listrik. Jakarta

[7] J. Siang, Jak. 2005. Dasar - Dasar Pengolahan Jaringan Syaraf Tiruan. Jakarta

[8] Kuncoro Arief Heru dan Dalimi Rinaldy. 2005 .Aplikasi Jaringan Syaraf Tiruan Untuk Peramalan Beban Tenaga Listrik Jangka Panjang Pada Sistem Kelistrikan Di Indonesia. Jurnal Program Pasca Sarjana, Fakultas Teknik, Universitas Indonesia.

[9] Puspitaningrum. 2006. Struktur Jaringan Syaraf Tiruan Backpropagation dan Radial Basis Function. Jakarta

[10] Syeto Galang Jiwo, Fariza Arna, S.Kom, M.Kom, Setiawardhana. S.T. 2010 .Peramalan Beban Listrik Menggunakan Jaringan Syaraf Tiruan Metode Kohonen. Makalah Program DIV Jurusan Teknik Informatika, Politeknik Elektronika Negeri Surabaya-Institusi Teknologi Sepuluh Nopember.

[11] S. N. Sivanandam, S. N Deepa.2006. Introduction to Neural Networks Using Matlab 6.0.New Delhi. 